\title{
Soybean Disease Loss Estimates for the Top 10 Soybean Producing Countries in 1994
}

\author{
J. A. Wrather, University of Missouri-Delta Center, P. O. Box 160, Portageville 63873; T. R. Anderson, Harrow \\ Research Center, Harrow, Ontario NOR 1 G0 Canada; D. M. Arsyad, Ministry of Agriculture, Agency for Agricul- \\ ture Research and Development, BORIF, Jalan Tentara Pelajar No. 3A, Bogor 16111, Indonesia; J. Gai, Soybean \\ Research Institute, Nanjing Agricultural University, Weigang, Nanjing, Jiangsu 210014, China; L. D. Ploper, \\ Estación Experimental Agroindustrial Obispo Colombres, Casilla de Correo 9, 4101 Las Talitas, Tucumán, R. Ar- \\ gentina; A. Porta-Puglia, Istituto Sperimentale per la Patologia Vegetale, Via Bertero 22, 00156 Roma, Italy; H. H. \\ Ram, G. B. Pant University of Agriculture \& Technology, Pantnagar - 263145, U. P., India; and J. T. Yorinori, \\ CNPSoja - EMBRAPA, Caixa postal 231, 86001-970 Londrina - Paraná - Brasil
}

\section{ABSTRACT}

Wrather, J. A., Anderson, T. R., Arsyad, D. M., Gai, J., Ploper, L. D., Porta-Puglia, A., Ram, H. H., and Yorinori, J. T. 1997. Soybean disease loss estimates for the top 10 soybean producing countries in 1994. Plant Dis. 81:107-110.

Soybean disease loss estimates were compiled for the 1994 harvested crop from the 10 countries with the greatest soybean production. The objective was to document the major soybean disease problems in these countries and any recent changes in the severity of individual soybean diseases. Total yield losses caused by Heterodera glycines in these 10 countries were greater than those caused by any other disease. Next in order of importance were stem canker, brown spot, and charcoal rot. The total yield loss due to disease during 1994 in these countries was 14.99 million metric tons, valued at $\$ 3.31$ billion. Methods used to estimate soybean disease losses were field surveys, plant disease diagnostic clinic samples, variety trial data, information from field workers and university extension staff, research plots, grower demonstrations, and private crop consultant reports. Yield loss estimates due to a particular disease varied by country. For example, yield losses due to rust were reported from China and Indonesia, but no losses due to this disease were reported from any of the remaining eight countries. Soybean disease control research and extension efforts are needed to provide more effective preventive and therapeutic disease management strategies and systems to producers.

During 1994, $137.82 \times 10^{6} \mathrm{t}$ of soybeans, Glycine $\max (\mathrm{L}$.$) Merr., were pro-$ duced on $62.44 \times 10^{6}$ ha worldwide (1). The majority, $134.08 \times 10^{6}$ t or $97.3 \%$, was produced in 10 countries, as follows: United States $\left(69.63 \times 10^{6} \mathrm{t}\right)$, Brazil $(25.50$ $\left.\times 10^{6} \mathrm{t}\right)$, China $\left(16.00 \times 10^{6} \mathrm{t}\right)$, Argentina $\left(12.40 \times 10^{6} \mathrm{t}\right)$, India $\left(3.30 \times 10^{6} \mathrm{t}\right)$, Canada $\left(2.25 \times 10^{6} \mathrm{t}\right)$, Paraguay $\left(2.20 \times 10^{6} \mathrm{t}\right)$, Indonesia $\left(1.60 \times 10^{6} \mathrm{t}\right)$, Italy $\left(0.65 \times 10^{6}\right.$ $\mathrm{t})$, and Bolivia $\left(0.55 \times 10^{6} \mathrm{t}\right)$. Other important soybean producing countries were Thailand $\left(0.48 \times 10^{6} \mathrm{t}\right)$, Mexico $(0.43 \times$ $\left.10^{6} \mathrm{t}\right)$, Russian Federation $\left(0.42 \times 10^{6} \mathrm{t}\right)$, North Korea $\left(0.40 \times 10^{6} \mathrm{t}\right)$, and France $\left(0.22 \times 10^{6} \mathrm{t}\right)$.

For many countries, soybeans are a significant source of income. At $\$ 220.50$ per $t$ $(\$ 6 / \mathrm{bu})$, the estimated value of the 1994

Corresponding author: J. A. Wrather

E-mail: plantaw@showme.missouri.edu

Accepted for publication 9 October 1996.

Publication no. D-1996-1118-05S

(c) 1997 The American Phytopathological Society harvested world crop in U.S. dollars was $\$ 30.39 \times 10^{9}$. The U.S. soybean crop alone was valued at $\$ 15.35 \times 10^{9}$. Factors that reduce soybean production, such as diseases, insects, weeds, and weather, can influence the welfare of many countries and individuals.

Diseases have been a major problem of soybean production in the northern (2) and southern (7) United States. For example, the estimated reduction in yield due to diseases and nematodes in the southern United States during 1994 was $1.20 \times 10^{6} \mathrm{t}$ (7). The soybean disease loss estimates for the entire United States have not been compiled, and soybean disease loss estimates for the other major producing countries have not been determined or are not readily available.

Our objective was to document the major soybean disease problems of the 10 countries with greatest soybean production during 1994. Where possible, we also documented any changes in the severity of individual soybean diseases within those countries during the last few years. The authors compiled the data for their country of residence; J. T. Yorinori also compiled data for Paraguay and Bolivia. Our purpose was to provide this information to help local and world agencies focus allocation of funds for research and to help scientists focus and coordinate research efforts. This information may also serve as a basis for future comparisons to determine changes in severity of individual diseases.

\section{MATERIALS AND METHODS}

Methods used to estimate soybean disease losses in these 10 countries were field surveys, plant disease diagnostic clinic samples, variety trial data, questionnaires to field workers and extension staff, research plots, grower demonstrations, and private crop consultant reports. Most individuals who reported estimates used several of these methods. Production losses were based on estimates of yield in the absence of disease. The disease loss estimates should not be construed as actual losses. The value of the loss estimates are in U.S. dollars.

Production loss estimates for each country are specific for the causal organism or the common name of the disease. The causal organisms of the diseases evaluated are in Table 1 (3).

Additional information on each disease can be found in the Compendium of Soybean Diseases (6).

\section{RESULTS AND DISCUSSION}

Argentina. Production of soybean in Argentina steadily expanded over the last two decades. Hectarage and total production increased from 344,000 ha and 496,000 t in 1974 to approximately 5.7 million ha and $11.3 \times 10^{6} \mathrm{t}$ in 1994 . Yields in the same period increased from 1,440 $\mathrm{kg} / \mathrm{ha}$ to almost $2,000 \mathrm{~kg} / \mathrm{ha}$.

More than $90 \%$ of Argentina's total production is in the northern Pampean subregion. This area includes the provinces of Córdoba, central and southern Santa Fe, northern Buenos Aires, and northeastern La Pampa. About 5\% of Argentina's pro- 
duction is in the northwestern region, which includes the provinces of Tucumán, Salta, Jujuy, northwestern Santiago del Estero, and east central Catamarca.

As soybean hectarage expanded in Argentina, the prevalence and severity of diseases also increased. The increased losses due to diseases were associated with germ plasm uniformity and lack of crop rotation. Yield losses due to diseases are in Table 2. In the northern Pampean subregion, the most economically important disease since the late 1970s has been Sclerotinia stem rot, caused by Sclerotinia sclerotiorum (Lib.) de Bary. Other less important endemic problems are anthracnose, Diaporthe-Phomopsis seed rot, and several viral diseases, including soybean mosaic virus, and less frequently, alfalfa mosaic, peanut mottle, and tobacco streak viruses. Other diseases that occasionally reduce yield are brown spot, purple stain, southern blight, charcoal rot, and Fusarium and Pythium spp. seedling rots. Recently, problems caused by nematodes, primarily Meloidogyne incognita (Kofoid \& White) Chitwood, M. javanica (Treub) Chitwood, and Pratylenchus spp., increased substantially. Since 1990, stem canker, sudden death syndrome, and Phytophthora root and stem rot have been identified as problems for the first time in this region. Only race 1 of Phytophthora has been detected in Argentina.

In the northwestern region, prevalent diseases are Phomopsis seed rot, purple stain, Rhizoctonia root and stem rot, and $M$. incognita. The incidence and severity of sudden death syndrome and Sclerotinia stem rot increased in the past 3 years, es- pecially where use of minimum tillage practices was widespread. Sudden death syndrome caused yield losses of up to $90 \%$ in individual fields. Sclerotinia stem rot is gradually becoming a serious limiting factor in many fields, particularly in the more humid part of this region. Diseases of minor importance but endemic in this part of the country are downy mildew, bacterial blight, target spot, and soybean mosaic. In addition, a foliar disease caused by Gonatophragmium mori was recently reported in this region. Zonate leaf spot was suggested as the common name for this disease.

Bolivia. Soybean production increased in Bolivia from 800 ha in 1972 to 331,000 ha in 1994. The biggest expansion occurred since 1989, when 140,000 ha were grown.

About $95 \%$ of the soybean crop is produced in the departamento (county) of Santa Cruz de la Sierra. Based on climate and soil types, the county could be divided into two different regions, northern and southern Santa Cruz. The northern region is characterized by flat, very fertile, heavy silt soil, and annual rainfall is above 1,400 $\mathrm{mm}$. Occasional flooding can occur after heavy rains. The soil type in southern Santa Cruz is mostly sandy, and the region is frequently affected by drought.

Two soybean crops are harvested each year in Bolivia. The main crop is grown during the summer. It is sown from late October to mid-December and harvested from late February to the end of April. The second crop, a winter crop, is about onethird the size of the summer crop and is grown in northern Santa Cruz. The winter crop is sown in May to June, and most of

Table 1. The causal organisms of yield-reducing soybean diseases in the top 10 soybean producing countries in 1994

\begin{tabular}{ll}
\hline Common name & Causal organism \\
\hline Anthracnose & Colletotrichum truncatum \\
Bacterial diseases & Pseudomonas syringae pv. glycinea, P. syringae pv. tabaci, \\
& Xanthomonas campestris pv. glycines \\
Brown spot & Septoria glycines \\
Brown stem rot & Phialophora gregata \\
Charcoal rot & Macrophomina phaseolina \\
Diaporthe-Phomopsis complex & Diaporthe and Phomopsis spp. \\
Downy mildew & Peronospora manshurica \\
Frogeye leaf spot & Cercospora sojina \\
Fusarium root rot & Fusarium spp. \\
Phytophthora root and stem rot & Phytophthora megasperma f. sp. glycinea \\
Pod and stem blight & Diaporthe phaseolorum var. sojae \\
Purple stain & Cercospora kikuchii \\
Rhizoctonia aerial blight & Rhizoctonia solani \\
Rhizoctonia-Pythium root rot & Rhizoctonia solani and Pythium spp. \\
Root-knot and other nematodes & Meloidogyne, Hoplolaimus, Pratylenchus, \\
& Rotylenchulus reniformis \\
Rust & Phakopsora pachyrhizi \\
Sclerotinia stem rot & Sclerotinia sclerotiorum \\
Southern blight & Sclerotium rolfsii \\
Seed disease & Alternaria, Cercospora, Corynespora, Cladosporium, \\
& and Fusarium spp. \\
Seedling diseases & Rhizoctonia, Pythium, and Fusarium spp. \\
Soybean cyst nematode & Heterodera glycines \\
Stem canker & Diaporthe phaseolorum var. caulivora \\
Sudden death syndrome & Fusarium solani form A \\
Thielaviopsis root rot & Thielaviopsis basicola \\
\hline
\end{tabular}

the production is used for seed in the following summer crop. The average winter crop yield is much lower $(1,600 \mathrm{~kg} / \mathrm{ha})$ than that of the summer crop $(2,450 \mathrm{~kg} / \mathrm{ha})$, but the seed is considered to be of higher quality. Diseases are most severe on the summer crop when average daily temperatures vary from 20 to $25^{\circ} \mathrm{C}$. The summer crop is occasionally rotated with cotton or corn, but monoculture is more common. Total soybean production in Bolivia is dependent on seed produced during the winter and seed imported from Brazil.

Soybean in Bolivia is affected by at least 17 diseases (Table 2). The average yield loss is estimated at 8 to $10 \%$, with annual losses valued at $\$ 9 \times 10^{6}$. The most common diseases caused by fungi in the winter crop are southern stem canker, frogeye leaf spot, Cercospora leaf blight, purple stain, brown spot, target spot, anthracnose, and downy mildew; common diseases in the summer crop are charcoal rot, Rhizoctonia root and stem rot, southern blight, Fusarium root rot, and Rosellinia root rot. The most common virus diseases are soybean mosaic (mostly on winter soybean) and bud blight. Bacterial pustule and bacterial blight are the most prevalent bacterial diseases. Root-knot nematodes constitute the most widespread nematode problem.

Brazil. The 1994 soybean crop was the largest ever in Brazil; over $25 \times 10^{6} \mathrm{t}$ was harvested from $11.5 \times 10^{6}$ ha. Yield losses to diseases were also large (Table 2). Annual yield losses due to diseases are estimated at $\$ 1 \times 10^{9}$.

Roughly half of the soybean hectarage in Brazil is located in the north central region states of Bahia, Goias, Minas Gerais, Maranhão, Mato Grosso, Mato Grosso do Sul, Piauí, and Tocantins. Soils there are generally low in fertility. The other half is in the southern states of São Paulo, Paraná, Santa Catarina, and Rio Grande do Sul.

With expansion of soybean production into new areas of Brazil and continued monocropping, some traditionally minor diseases and some new ones have caused increasing damage to soybean. Some diseases are restricted to certain regions, such as bud blight in the state of Paraná, brown stem rot in the states of Rio Grande do Sul and Santa Catarina, and Sclerotinia stem rot in the states of Paraná, Santa Catarina, and Rio Grande do Sul. Rhizoctonia aerial blight is in Maranhão, Mato Grosso, and Piauí, and southern blight and Rhizoctonia damping-off are in the states of Paraná, São Paulo, and Rio Grande do Sul. Several diseases are of minor importance, with limited distribution (rust and Ascochyta and Myrothecium leaf spots) or wide distribution (bacterial blight, downy mildew, Rosellinia root rot, target spot, and soybean mosaic virus).

Anthracnose and pod and stem rot used to be minor to occasionally severe diseases in the southern soybean production region. In recent years, however, they were fre- 
quently responsible for severe losses in the rainy central and northern portions of Brazil. When severe, these diseases may cause complete pod abortion. In addition to yield loss in the field, these diseases cause postharvest losses when infected seed are discarded due to poor germination.

In the 1989 crop season, southern stem canker was first reported in the states of Paraná and Mato Grosso. Since then, it has spread to all soybean production areas in the country. This disease has caused yield reductions from 0 to $100 \%$ in individual fields. Since 1989, yield losses due to southern stem canker were valued at more than $\$ 3.0 \times 10^{6}$. In 1994 alone, the losses attributed to this disease were valued at $\$ 2.5 \times 10^{6}$. It is expected that within a few years, southern stem canker will be under control through planting of resistant varieties. Two of the most conspicuous diseases in Brazil are brown spot and Cercospora leaf blight. Both are responsible for early defoliation, and annual yield losses are estimated at $7 \%$. Yield loss studies carried out with fungicides have shown that yield reduction in individual fields can be as high as $47 \%$. The better the rain distribution during the crop season, the greater the losses due to these foliar diseases. Both diseases usually occur together.

Charcoal rot was responsible for significant yield reductions in the drought-prone southern (Paraná, São Paulo, Rio Grande do Sul, and southern Mato Grosso do Sul) and eastern (Bahia, Tocantins, and northern Goias) states. This disease can reduce yield in these regions by as much as $50 \%$ overall whenever a drought occurs in January. When abundant rainfall follows the dry spell, the plants that are weakened by charcoal rot become more susceptible to the late foliar diseases, which increases the total yield loss caused by charcoal rot.

Losses caused by sudden death syndrome have greatly increased during 1991 to 1994, and this disease is becoming important in the southern states and in the high plains of the savanna region. Yield losses have been as high as 30 to $40 \%$ in individual fields.

In the 1994 crop season, Phytophthora root and stem rot caused severe damage in some fields in the high plains of Rio Grande do Sul. This is the first report of this disease in Brazil.

Root-knot nematodes (M. incognita and $M$. javanica) are widely distributed and frequently cause substantial yield reductions. The soybean cyst nematode, Heterodera glycines Ichinohe, which was first reported in Brazil in 1992 (4), was estimated to infest about 10,000 ha of four counties in the states of Goias, Minas Gerais, Mato Grosso, and Mato Grosso do Sul. Yield losses in the first year were valued at $\$ 1 \times 10^{6}$. In 1994, the nematode was found in 46 counties in six states, including the states of São Paulo and Rio Grande do Sul. More than $1 \times 10^{6}$ ha were estimated to be infested in 1994. Total yield losses due to this nematode in the past 4 years were valued at more than $\$ 130 \times 10^{6}$.

Canada. In Canada, soybean is grown in the provinces of Ontario (769,000 ha), Quebec (60,705 ha), and Prince Edward
Island (6,071 ha). The majority of production is in southwestern Ontario, where soybean has been grown since the mid1940s. Ontario is also the area with the most numerous and severe disease problems, although disease losses in 1994 were less than normal because of ideal environmental conditions for the crop (Table 2).

Phytophthora root and stem rot was a major disease until the introduction of multi-race-resistant cultivars with high levels of tolerance. The recent increase in prevalence of new virulent races of Phytophthora is a concern. Since it was first found in Ontario in 1987, H. glycines damage has increased dramatically on sandy loam and loam soils. This disease has increased in severity in individual fields and continues to spread into new areas of the province. It is estimated that 60,000 ha are now infested there. Sclerotinia stem rot has historically been a sporadic problem, but recently this disease increased in frequency and severity. It was severe in 1994. Rhizoctonia-Fusarium root rots frequently cause stunting under wet conditions.

China. Soybean planting is increasing in northeastern China, and losses to disease are high (Table 2). In this area, losses caused by $H$. glycines, Fusarium wilt, frogeye leaf spot, and downy mildew are increasing due to continuous planting of soybean.

India. Yellow mosaic virus has caused considerable damage in the northern part of India, particularly in the Tarai region adjacent to the foothills of the Himalayas. This virus hindered expansion of soybean pro-

Table 2. Estimated reduction of soybean yields in metric tons for the top 10 soybean producing countries during 1994

\begin{tabular}{|c|c|c|c|c|c|c|c|c|c|c|c|}
\hline Diseases & Arg. & Bol. & Braz. & Can. & China & India & Indon. & Italy & Para. & U.S. & Total \\
\hline Anthracnose & 36,700 & 3,000 & 77,500 & $\cdots$ & $\ldots$ & 35,000 & 40 & 700 & 12,200 & 71,400 & 236,400 \\
\hline Bacterial diseases & 12,200 & & & $\ldots$ & $\ldots$ & 70,000 & 160 & $\ldots$ & & 44,600 & 127,000 \\
\hline Brown spot & 36,600 & 8,900 & $1,100,000$ & 700 & $\ldots$ & $\ldots$ & $\ldots$ & $\ldots$ & 61,100 & 75,400 & $1,282,700$ \\
\hline Brown stem rot & 36,700 & $\ldots$ & 6,200 & $\ldots$ & $\ldots$ & $\ldots$ & 20 & $\ldots$ & & 263,300 & 306,200 \\
\hline Charcoal rot & 16,300 & & 930,000 & 700 & $\ldots$ & $\ldots$ & $\ldots$ & . & 12,200 & 275,000 & $1,234,300$ \\
\hline $\begin{array}{l}\text { Diaporthe-Phomopsis } \\
\text { complex }\end{array}$ & 85,500 & 1,500 & 62,000 & 4,500 & $\ldots$ & $\ldots$ & $\ldots$ & 1,000 & $\ldots$ & 31,500 & 186,000 \\
\hline Downy mildew & 12,300 & & $\cdots$ & 500 & 363,800 & $\ldots$ & $\cdots$ & 1,000 & $\ldots$ & 10,500 & 387,900 \\
\hline Frogeye leaf spot & $\ldots$ & 2,000 & $\ldots$ & $\ldots$ & 504,800 & $\ldots$ & 20 & $\ldots$ & $\ldots$ & $\ldots$ & 506,800 \\
\hline Fusarium root rot & & & & & 220,600 & 35,000 & 40 & $\ldots$ & $\ldots$ & 68,000 & 323,700 \\
\hline Other diseases ${ }^{\mathrm{a}}$ & 12,200 & 16,400 & 20,000 & 700 & $\ldots$ & $\ldots$ & $\ldots$ & & $\ldots$ & 73,100 & 122,400 \\
\hline Phytophthora rot & 16,300 & $\ldots$ & 8,000 & 11,300 & $\ldots$ & & $\ldots$ & 2,000 & & 560,300 & 597,800 \\
\hline Pod and stem blight & & & 31,000 & $\ldots$ & $\ldots$ & 105,000 & 20 & 1,400 & 2,400 & 125,600 & 265,400 \\
\hline Purple stain & 24,400 & 8,900 & 930,000 & $\ldots$ & $\ldots$ & & $\ldots$ & $\ldots$ & 49,000 & 74,800 & $1,087,000$ \\
\hline Rhizoctonia aerial blight & $\ldots$ & $\ldots$ & 4,100 & & $\ldots$ & 70,000 & $\ldots$ & $\ldots$ & $\ldots$ & 30,600 & 104,700 \\
\hline $\begin{array}{l}\text { Rhizoctonia-Pythium root } \\
\text { rot }\end{array}$ & $\ldots$ & $\ldots$ & 31,000 & 9,000 & $\ldots$ & $\ldots$ & 40 & $\ldots$ & $\ldots$ & 68,000 & 108,000 \\
\hline $\begin{array}{l}\text { Root-knot and other } \\
\text { nematodes }\end{array}$ & 158,800 & $\ldots$ & 77,500 & $\ldots$ & $\ldots$ & $\ldots$ & $\ldots$ & $\ldots$ & 2,400 & 116,000 & 354,700 \\
\hline Rust & & $\ldots$ & & & 253,500 & $\ldots$ & 200 & & $\ldots$ & & 253,700 \\
\hline Sclerotinia stem rot & 183,300 & $\ldots$ & 150,000 & 11,300 & 77,300 & $\ldots$ & $\ldots$ & 3,000 & $\ldots$ & 636,400 & $1,061,200$ \\
\hline Southern blight & 16,300 & & & & $\ldots$ & $\ldots$ & $\ldots$ & $\ldots$ & & & 16,300 \\
\hline Seed disease & & 1,500 & 155,000 & 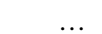 & $\ldots$ & $\ldots$ & $\ldots$ & $\ldots$ & 5,500 & 48,000 & 210,000 \\
\hline Seedling disease & 24,400 & $\ldots$ & 50,000 & 11,300 & & $\ldots$ & $\ldots$ & 700 & 5,000 & 198,700 & 289,900 \\
\hline Soybean cyst nematode & & & 310,000 & 18,000 & 707,400 & $\ldots$ & $\ldots$ & & & $1,990,000$ & $3,025,400$ \\
\hline Stem canker & 12,200 & 3,000 & $1,800,000$ & 1,100 & $\ldots$ & $\ldots$ & $\ldots$ & 3,000 & 85,600 & 41,400 & $1,946,200$ \\
\hline Sudden death syndrome & 134,400 & & 15,000 & $\ldots$ & $\ldots$ & $\ldots$ & $\ldots$ & & $\ldots$ & 89,400 & 238,700 \\
\hline Virus & 85,500 & 1,500 & $\ldots$ & $\ldots$ & 457,300 & 105,000 & 120 & 1,300 & $\ldots$ & 70,600 & 721,400 \\
\hline
\end{tabular}

a Alternaria spp. and Corynespora cassiicola in Argentina; Corynespora spp., Rosellinia spp., Rhizoctonia root decay, Ascochyta spp., Myrothecium leaf spot, and downy mildew in Brazil and Bolivia; and Thielaviopsis root rot in Canada. 
duction in northern India in the late 1960s, when the soybean crop was introduced from the United States for commercial cultivation. However, advances in the development and release of soybean cultivars resistant to this virus have made soybean production possible in the Tarai region. Soybean rust severely damaged the soybean crop in northern India until the mid1970s. Since then, rust-resistant cultivars have been released and the problem is much less severe, but yield losses still occur (Table 2).

Indonesia. Sixty percent of Indonesia's soybean crop is produced during the dry months after rice, and $40 \%$ is produced during the rainy months, usually after upland crops such as rice or legumes. Soybean diseases are severe (Table 2), especially in the dryland areas where environmental conditions are favorable for diseases. The most important disease of soybean in Indonesia is rust. In the last several years, diseases caused by viruses became more serious in the Java and Lampung Provinces due to continuous cropping of soybean.

Italy. The hectarage of soybean in Italy increased from 317 ha in 1981 to 513,789 ha in 1991 and then declined to 172,000 ha in 1995. Yield per ha was unchanged from 1990 to 1995.

The total production in 1994 was $652,000 \mathrm{t}$. The major soybean producing areas are in northern Italy, mostly in the eastern and central part of the Po Valley.

Several pathogens have been recorded on soybean in Italy. Although there are sporadic reports of economically important damage caused by viruses, bacteria, fungi, and nematodes, the health condition of the crop is satisfactory in general. The popularity of crop rotation, the differentiation of germ plasm (at least 15 cultivars are grown), and high seed quality (most imported from North America) account for the rarity of epidemics.

Among fungal diseases, stem canker, Phytophthora root and stem rot, and Sclerotinia stem rot are of concern, and limited epidemics were observed in some areas. Incidence of stem canker is increasing, whereas incidence of Phytophthora root and stem rot and Sclerotinia stem rot is decreasing. The decline in the latter two diseases is probably due to crop rotation and the use of Sclerotinia-resistant or -tolerant cultivars. Downy mildew causes sporadic damage. Anthracnose is frequently observed in the field, but incidence is low. Seed decay caused by the Diaporthe-Phomopsis complex has frequently been observed. In moist, heavy soils, preemergence damping-off and root and stem rot caused by $R$. solani have also been reported. Soybean mosaic virus, detected on seeds and on plants in the field, is the major virus disease of soybean. Rootknot nematode ( $M$. incognita) damage is considered minor.
Paraguay. Soybean in Paraguay is grown mostly in those counties bordering Brazil, where fertile soil predominates. Rainfall is usually adequate, ranging from 1,200 to $1,450 \mathrm{~mm}$ during the crop season (October to May), but occasional dry spells may affect yield. Average yields range from 2,500 to $3,800 \mathrm{~kg} / \mathrm{ha}$.

Until recently, soybean diseases were of little concern in Paraguay. Only after southern stem canker became a problem in the 1991 to 1992 and 1992 to 1993 crop seasons were diseases regarded as a threat. Disease surveys carried out since then showed that some diseases may reduce yield significantly. Abundant soybean plant growth due to fertile soils, monocropping, increasing adoption of no-tillage practices, and high plant populations is partly responsible for increased disease problems. Losses for 1994 are in Table 2.

Southern stem canker was the most devastating disease recorded in Paraguay. During 1991 to 1992 and 1992 to 1993 , several fields had yield losses ranging from $50 \%$ to almost total loss. In the following two crop seasons, the introduction of resistant varieties from Brazil helped reduce the disease incidence. The government of Paraguay allocated funds to promote research, extension work, and seed production of varieties resistant to this disease after its outbreak.

Other diseases that are regarded as important and that occasionally contribute to yield reduction are anthracnose, Rhizoctonia and Fusarium root rots, and southern blight. Phomopsis, Colletotrichum, Rhizoctonia, and Fusarium spp. are the major seedborne pathogens that affect seed quality when harvesting is delayed due to prolonged rain. Root-knot nematode ( $M$. javanica) is regarded as of minor importance.

United States. The majority of soybeans produced in the United States during 1994 were from Iowa, Illinois, Minnesota, Indiana, Ohio, Missouri, Nebraska, South Dakota, Kansas, Wisconsin, Michigan, and North Dakota. These north central region states produced $81 \%$ of the 1994 U.S. crop. Fifteen states in the midsouth and southeastern regions produced $18 \%$ of the crop that year. Soybean yield losses in the United States in 1994 (Table 2) were valued at $\$ 968.8 \times 10^{6}\left(4.39 \times 10^{6} \mathrm{t} \times\right.$ $\$ 220.50 / \mathrm{t}$ ).

Yield loss estimates for the United States during 1994 were compiled by adding the losses from the south (7) and from the north central region. The yield loss estimates for the north central region states during 1994 were provided by several land grant university plant pathologists. Soybean yield losses due to diseases varied by region in the United States. Anthracnose, purple stain, charcoal rot, pod and stem rot, root-knot nematode, stem canker, sudden death syndrome, and viruses caused more losses in the southern than in the northern regions. Sudden death syndrome, root-knot nematode, and downy mildew did not cause any loss in the north. Brown stem rot and Sclerotinia stem rot caused yield losses only in the northern region.

The greatest losses across the United States in 1994 were caused by $H$. glycines $\left(1.99 \times 10^{6} \mathrm{t}\right)$, followed by Sclerotinia stem rot $\left(0.64 \times 10^{6} \mathrm{t}\right)$, Phytophthora root and stem rot $\left(0.56 \times 10^{6} \mathrm{t}\right)$, charcoal rot $(0.28 \times$ $\left.10^{6} \mathrm{t}\right)$, and brown stem rot $\left(0.26 \times 10^{6} \mathrm{t}\right)$. Yield losses caused by $H$. glycines recently declined in the south (7) but increased in the north (5). Sclerotinia stem rot recently caused heavy yield losses in the north central region, especially in Michigan, Minnesota, Ohio, and Wisconsin, but minimal losses in this region during 1989 to 1991 (2).

Clearly, diseases caused extensive reductions in soybean yield in these 10 countries during 1994. The total yield loss was $14.99 \times 10^{6} \mathrm{t}$, valued at $\$ 3.31 \times 10^{9}$. Yield losses in some countries may have been worse if not for the use of disease management strategies and systems in most countries. Scientists at the universities in these countries developed most of the disease-resistant cultivars and alternative disease management strategies and systems available to growers. To reduce disease losses, research and extension efforts must be expanded to provide more effective preventive and therapeutic disease management strategies and systems to producers.

\section{ACKNOWLEDGMENTS}

Published as Journal Series 12,479 of the University of Missouri Agriculture Experiment Station. We thank Joyce Elrod for her efforts in this project. We thank Walker Kirby, Scott Abney, Don Scott, Fred Schwenk, Pat Hart, Ward Stienstra, David Wysong, Berlin Nelson, Patrick Lipps, Tom Chase, and Craig Grau for providing soybean disease loss estimate data for the north central United States.

\section{LITERATURE CITED}

1. Anonymous. 1995. Oilseeds: World Markets and Trade. U.S. Dep. Agric. Foreign Agric. Serv. Circ. Ser. FOP 9-95:20.

2. Doupnik, B., Jr. 1993. Soybean production and disease loss estimates for north central United States from 1989 to 1991. Plant Dis. 77:11701171.

3. Lim, S. M., and Chamberlain, D. W., eds. 1994. Diseases of soybean. Common Names for Plant Diseases 1994. American Phytopathological Society, St. Paul, MN.

4. Monteiro, A. R., and Morais, S. R. A. C. 1992. Ocorrência de nematóide de cisto da soja, Heterodera glycines Ichinohe, prejudicando a cultura no Mato Grosso do Sul. Congresso Brasileiro De Nematologia 16:207-209.

5. Noel, G. R. 1992. History, distribution, and economics. Pages 1-13 in: Biology and Management of the Soybean Cyst Nematode. R. D. Riggs and J. A. Wrather, eds. American Phytopathological Society, St. Paul, MN.

6. Sinclair, J. B., and Backman, P. A., eds. 1989. Compendium of Soybean Diseases. 3rd ed. American Phytopathological Society, St. Paul, MN

7. Wrather, J. A., Chambers, A. Y., Fox, J. A., Moore, W. F., and Sciumbato, G. L. 1995. Soybean disease loss estimates for the southern United States, 1974 to 1994. Plant Dis. 79:1076-1079. 